\title{
IMPACT OF USING PHOTOVOLTAIC PANELS IN PIGGERY ON GREENHOUSE GASES EMISSION
}

Wojciech RZEŹNIK, Institute of Technology and Life Sciences, Department of the Technology and Emissions Development in Farms, Biskupińska 67, 60-463 Poznań, Poland, w.rzeznik@itp.edu.pl (corresponding author)

Ilona RZEŹNIK, Institute of Environmental Engineering, Poznan University of Technology, Piotrowo 3a, 61-138 Poznań, Poland, ilona.rzeznik@put.poznan.pl

Paulina MIELCAREK, Institute of Technology and Life Sciences, Department of the Technology and Emissions Development in Farms, Biskupińska 67, 60-463 Poznań, Poland, p.mielcarek@itp.edu.pl

Farm buildings have a large number of unused roofs, where photovoltaic panels may be installed without limiting the agricultural land. In piggeries the largest demand for electricity has the ventilation system. The daily distribution of electricity demand is correlated to the diurnal variation of solar radiation. This allows immediate use the energy produced by photovoltaic panels. The aim of the study was to determine the energy demand of the ventilation system, to design a photovoltaic system for its operation and to determine the $\mathrm{CO}_{2}$ emission reduction. The research was carried out for the deep-litter piggery located in Poland. The demand for electricity was determined on the basis of three-year measurements of electricity consumption in the studied piggery. The photovoltaic system was designed to power the ventilation system. Mean annual demand was $26046 \mathrm{kWh}$. The designed PV system has power of $27 \mathrm{kWp}\left(23984 \mathrm{kWh} \mathrm{yr}{ }^{-1}\right)$. Energy deficits $\left(4591 \mathrm{kWh} \cdot \mathrm{yr}^{-1}\right)$ were noted for 8 months, and energy surpluses $\left(2528 \mathrm{kWh} \cdot \mathrm{yr}^{-1}\right)$ for 4 months in a year. The reduction of $\mathrm{CO}_{2}$ emissions resulting from the use of a photovoltaic system to supply the ventilation system is $19.1 \mathrm{Mg} \mathrm{CO}_{2} \cdot \mathrm{yr}^{-1}$ and represents $3 \%$ of the total greenhouse gases emissions from the piggery, expressed in $\mathrm{CO}_{2}$ equivalent. It may increase to $8.6 \%$ in case of installing the maximum number of PV panels system (maximum power of $78 \mathrm{kWp}$; total energy production $68526 \mathrm{kWh} \mathrm{yr}^{-1}$ ) on the southern part of the roof, but it requires the financial support for renewable energy by the government.

Keywords: PV panels, carbon dioxide emission, farm building, renewable energy

\section{INTRODUCTION}

Population growth, technological and economic development increase the demand for energy. Energy production from traditional fossil fuels causes a number of environmental problems such: climate change, global warming, air pollution and acid rain. Therefore, there is a need to develop the renewable energy market in order to meet the political, economic and environmental challenges associated with the generation of electricity (Sampaio and González, 2017).

Solar energy is clean and reliable natural energy, the most safety and widely available. The most popular way of utilizing it in the world is electricity production using photovoltaic panels (Soufi et al., 2015; Xue, 2017). Production of electricity from sunlight by PV panels is one of the most promising renewable energy markets. Due to the perspective of rapid growth and high levels of investment involved, the photovoltaic market is getting more interest around the world, especially in Europe, China and in the United States (Razykov et al., 2011; Hosenuzzaman et al., 2015).

The leader in the energy production by PV panels in Europe is Germany. They have seen the potential for renewable energy production in the agricultural sector (Wood, 2006). Many agricultural producers, supported by subsidies for photovoltaic systems, produce electricity based on these systems. In Poland, the share of solar energy in 2016 was only $0.5 \%$ of the installed power in the national energy system, and in Germany, it was 6.9\% (Philipps, 2017; PV market..., 2017).

Agricultural production, like other sectors of the economy, needs electricity, which is produced mainly from coal, natural gas and crude oil (Karkolin et al., 2006). This sector has a high energy demand, used for vehicle operation, greenhouse air conditioning, cereal drying and ventilation and heating of livestock buildings (Ozkan et al., 2004). On the other hand, agriculture has a large amount of land and roof areas, where the photovoltaic systems may be installed. Locating these systems on the ground involves the exclusion of this area from agricultural production and it needs the purchase of a support construction. The use of roofs of agricultural buildings for this purpose reduces the investment costs and does not limit the agricultural land. Moreover, in livestock buildings, the electricity from PV systems may be also consumed. Romantchik et al. (2017) designed a photovoltaic system that covered 100\% of the energy demand for greenhouse ventilation. Bey et al. (2016) showed that the PV system with battery storage may provide the energy required for the operation of the barn for dairy cows. Another place to use solar energy may be livestock buildings for pigs. The largest consumer of electricity in piggeries is the ventilation system. Its demand throughout the day is correlated to the level solar radiation. This allows for immediate use of the energy produced by PV panels.

Copyright (C) 2017 The Authors. Published by Aleksandras Stulginskis University. This is an open-access article distributed under the terms of the Creative Commons Attribution License (CC-BY 4.0), which permits unrestricted use, distribution, and reproduction in any medium, provided the original author and source are credited. 
The aim of the study was to determine the energy demand of the ventilation system, to design a photovoltaic system for its operation and to determine the $\mathrm{CO}_{2}$ emission reduction resulting from the use of PV panels.

\section{MATERIALS AND METHODS}

The research was carried out in a farm located in the Wielkopolska Voivodship, Poland. Measurements of the energy demand of the ventilation system and the simulations of the photovoltaic system operation were made for commercial deep-litter piggery. The basic parameters of this building are presented in Table 1.

Table 1. Technical and production parameters of studied piggery

\begin{tabular}{|l|c|}
\hline Parameter & Value \\
\hline Dimensions of piggery (length/width/height) $(\mathrm{m})$ & $48 / 25 / 4.7$ \\
\hline Roof slope angle $\left(^{\circ}\right)$ & 20 \\
\hline Dimensions of roof (length/width) $(\mathrm{m})$ & $48 / 26.6$ \\
\hline Number of pens & 19 \\
\hline Number of pigs & 950 \\
\hline Area per pig $\left(\mathrm{m}^{2} \cdot \mathrm{pig}^{-1}\right)$ & 0.77 \\
\hline
\end{tabular}

The piggery was equipped with mechanical under pressure ventilation system. It has 19 fans with nominal efficiency of $6250 \mathrm{~m}^{3} \cdot \mathrm{h}^{-1}$ and maximum power of $280 \mathrm{~W}$, each. The ventilation rate was regulated basing on the inside temperature (microclimate controller, SK-1D2M Wesstron, Poland). The average monthly energy demand of this system was determined on the basis of three-year measurements of electricity consumption (Kamstrup K-383 electricity meter connected to a PC).

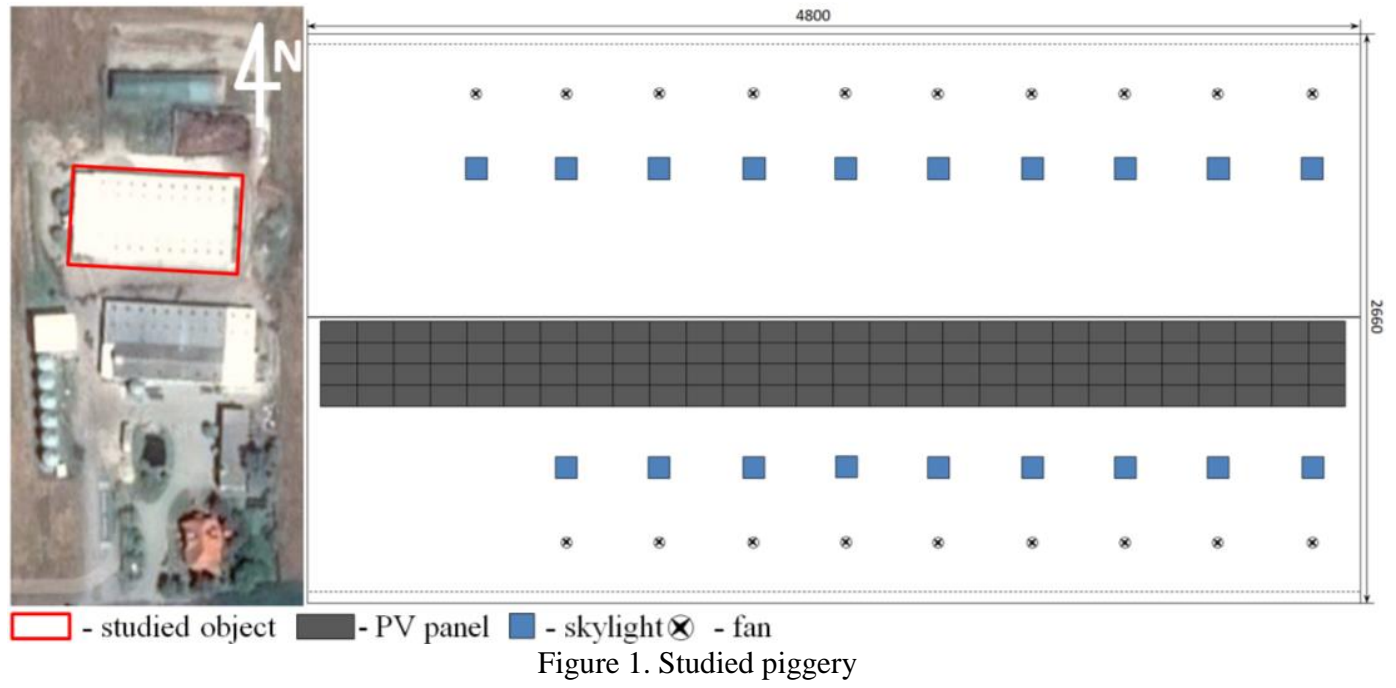

The PV panels - Selfa SV60P-245 (Table 2) are to be installed directly on the southern part of the roof (Fig. 1). The system is an on-grid solar power, so it is connected to the utility grid. It allows the sale of surplus energy and the purchase of energy during period of its deficit.

Table. 2. Technical specification of PV panel- Selfa SV60P-245

\begin{tabular}{|l|c|}
\hline Parameter & Value \\
\hline Maximum power $(+3 \% ;-0 \%)(\mathrm{W})$ & 245 \\
\hline Voltage at maximum power $(\mathrm{V})$ & 30.5 \\
\hline Current at maximum power $(\mathrm{A})$ & 8.05 \\
\hline Short-circuit current $(\mathrm{A})$ & 8.60 \\
\hline Open-circuit $(\mathrm{V})$ & 37.9 \\
\hline Efficiency $(\%)$ & 15 \\
\hline Area $\left(\mathrm{m}^{2}\right)$ & 1.642 \\
\hline Mass $(\mathrm{kg})$ & 20 \\
\hline
\end{tabular}

The efficiency of the elements of the designed system and the whole system is calculated from equations (1) and (2):

$$
P R_{n}=\left(1-L_{n} \cdot 100^{-1}\right)
$$

where:

\footnotetext{
$L_{1}-\mathrm{DC}$ and AC cables losses $(2 \%)$

$L_{2}$ - inverter losses $(2 \%)$

$L_{3}$ - temperature losses (4\%)
} 
$L_{4}$ - losses due to week radiation $(3 \%)$

$L_{5}$ - losses due to dust, snow etc. (4\%)

$L_{6}$ - losses of shunt diodes $(0.5 \%)$

$P R=P R_{l} \cdot P R_{2} \cdot P R_{3} \cdot P R_{4} \cdot P R_{5} \cdot P R_{6}$

where:

$P R$ - performance ratio

The annual energy output produced by the designed photovoltaic system was determined from the equation (3):

$$
E O=n \cdot A \cdot r \cdot S_{E} \cdot P R
$$

where:

$n$ - number of PV panels

$A$ - area of PV panel

$R$ - solar panel efficiency (15\%)

$S_{E}$ - mean monthly solar energy $\left(\mathrm{kWh} \cdot \mathrm{m}^{-2}\right)$

The calculations were made for monthly average long-term solar radiation intensity values monitored in the years 1971-2000 for the Wielkopolska Region (Emission factor..., 2017).

\section{RESULTS AND DISCUSION}

Based on a three-year measurement of electricity consumption in the years 2013-2015, the mean annual demand of the ventilation system in piggery was determined. It was $26046 \mathrm{kWh}$ per year. Distribution of mean electricity consumption in each month of the year is presented in Table 3.

Table 3. Energy demand for ventilation system

\begin{tabular}{|c|c|c|c|c|c|c|c|c|c|c|c|c|}
\hline Month & Jan & Feb & Mar & Apr & May & Jun & Jul & Aug & Sep & Oct & Nov & Dec \\
\hline $\begin{array}{c}\text { Energy } \\
\text { demand } \\
(\mathrm{kWh})\end{array}$ & 1299 & 1200 & 1454 & 1843 & 2766 & 2997 & 3453 & 3263 & 2624 & 2021 & 1595 & 1531 \\
\hline
\end{tabular}

The mean solar radiation data for each month is shown in Fig. 2.

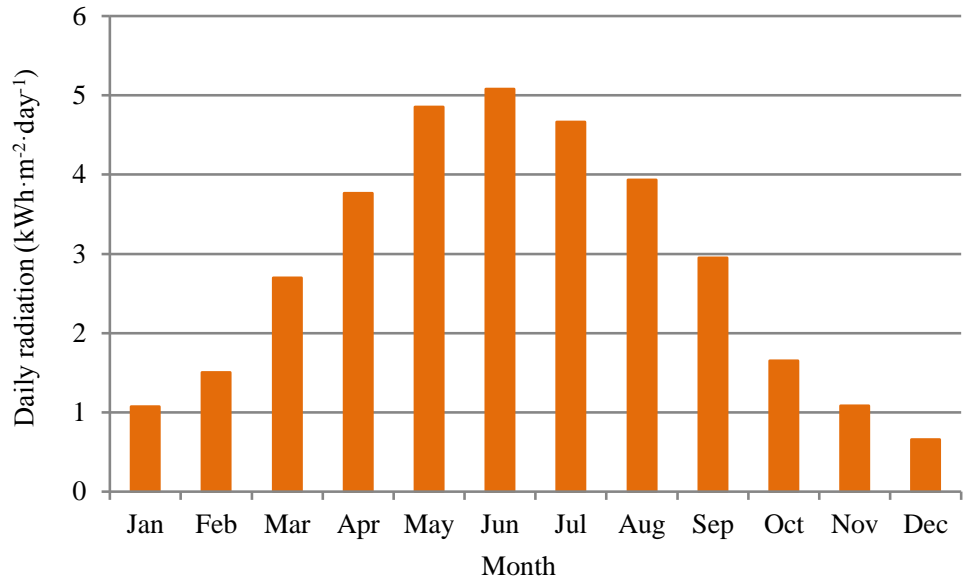

Figure 2. The daily solar radiation in Wielkopolska Voivodship, Poland

The data are published every year by the Ministry of Infrastructure and Construction (Emission factors..., 2017). The elaboration contains typical meteorological years and the statistical data on climate in Poland, by regions. It has been prepared for energy calculations in the building industry and can be used in calculating the energy performance of buildings, drawing up energy certificates for buildings and for designing and energy simulations of buildings in professional and development application.

The electricity demand of the ventilation system of piggery is similar to the distribution of solar radiation during the year, which allows use of the electricity immediately after generation by PV panels.

It was assumed that the annual electricity output per $\mathrm{kWp}$ of installed power is $950 \mathrm{kWh} \cdot \mathrm{kWp}^{-1}$ (Sibiński and Znajdek, 2016). Based on the calculations, the PV system needs $27 \mathrm{kWp}$ to cover the demand for the ventilation system. It consists of 112 Selfa SV60P-245 photovoltaic panels (total area of $184 \mathrm{~m}^{2}$ ), POWADOR 30.TL3.INT inverter, energy meters, grid connection, safety and protection equipment. The energy parameters of the system in each month are shown in Table 4

The designed system can produce $23984 \mathrm{kWh}$ of electricity per year. It does not cover the total energy demand of the ventilation system. The surplus generated during the year is $2528 \mathrm{kWh}$ and the deficit is $4591 \mathrm{kWh}$ (Fig. 3). The cost of designed photovoltaic system is 157000 PLN (37000 EUR) and a payback time (SPBT-Simple Pay Back Time) is 12.6 
years. Installing more panels is not economically justified, because surplus of electricity is purchased by the energy companies for $100 \%$ of the price applicable in the Energy Regulatory Office, without financial bonus. Assuming appropriate government financial support, photovoltaic panels could be installed on the all southern part of the roof (320 panels), which would generate $68526 \mathrm{kWh}$ of electricity per year.

Table 4. The energetic parameters of photovoltaic system

\begin{tabular}{|c|c|c|c|c|c|c|c|c|c|c|c|c|}
\hline Month & Jan & Feb & Mar & Apr & May & Jun & Jul & Aug & Sep & Oct & Nov & Dec \\
\hline $\begin{array}{c}\text { Solar energy } \\
\text { (kWh) }\end{array}$ & 6024 & 7619 & 15157 & 20454 & 27262 & 27584 & 261687 & 22086 & 16023 & 9257 & 5885 & 3680 \\
\hline $\begin{array}{c}\text { Energy output } \\
\text { of PV system } \\
\text { (kWh) }\end{array}$ & 772 & 976 & 1942 & 2620 & 3492 & 3534 & 3355 & 2829 & 2053 & 1186 & 754 & 471 \\
\hline
\end{tabular}

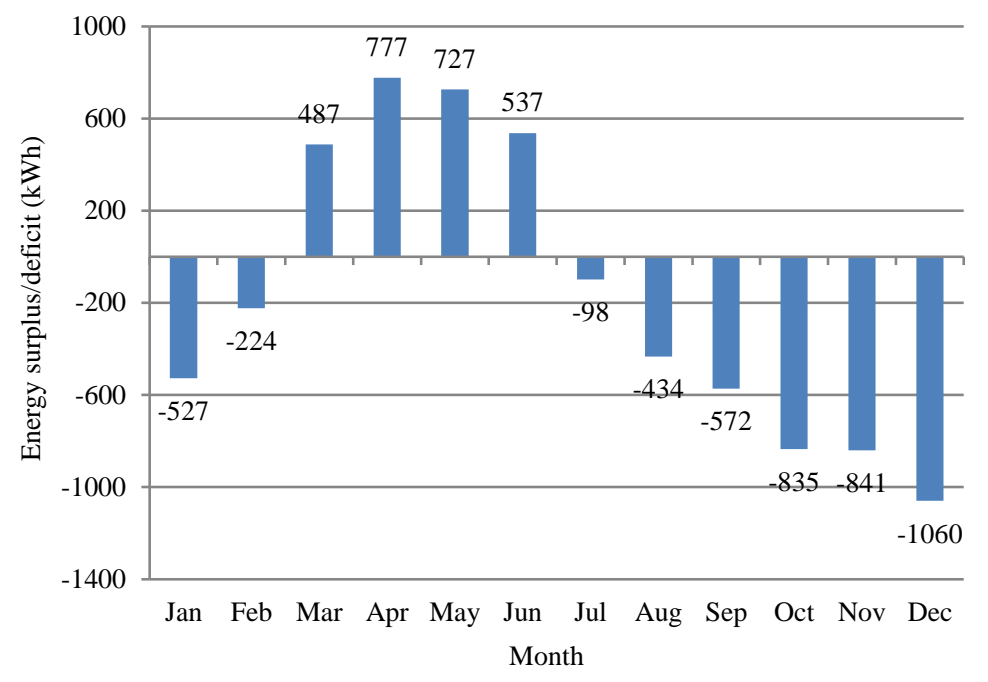

Figure 3. Energy surplus or deficit

The reduction of carbon dioxide emissions from the PV system was calculated basing on the carbon dioxide emission factor expressed per $1 \mathrm{kWh}$ of electricity from the national energy system. The factor published by The National Centre for Emissions Management in February 2017 was $798 \mathrm{~kg} \cdot \mathrm{MWh}^{-1}$ (KOBIZE, 2017). The reduction of $\mathrm{CO}_{2}$ emissions resulting from the use of the PV system to supply the ventilation system of piggery is $19.1 \mathrm{Mg} \mathrm{CO}_{2} \cdot \mathrm{yr}^{-1}$. Installation of maximum number of panels on the southern part of the roof would reduce the emission of this gas by $54.7 \mathrm{Mg} \mathrm{CO}_{2} \cdot \mathrm{yr}^{-1}$.

The total greenhouse gases emission from the analyzed piggery was calculated on the basis of the $\mathrm{CH}_{4}$ and $\mathrm{N}_{2} \mathrm{O}$ emission factors for this building, respectively: $18.1 \mathrm{~kg} \cdot \mathrm{pig}^{-1} \cdot \mathrm{yr}^{-1}$ and $0.78 \mathrm{~kg} \cdot \mathrm{pig}^{-1} \cdot \mathrm{yr}^{-1}$ (Program, 2011). It was assumed that carbon dioxide emitted from the piggery was consumed by photosynthesis of plants for animal feed. The annual greenhouse gas emission from the building expressed in $\mathrm{CO}_{2}$ equivalent was $614.9 \mathrm{Mg}$ eq. $\cdot \mathrm{CO}_{2} \cdot \mathrm{yr}^{-1}$.

The emission reduction caused by the photovoltaic system is $3 \%$ of the total greenhouse gases emissions from the piggery, expressed in $\mathrm{CO}_{2}$ equivalent, and $8.6 \%$ in case of $\mathrm{PV}$ panels installation on the all southern part of the roof. It is possible to limit gas emissions by modernizing the piggery or equipping it with additional facilities, but the investment costs are much higher than in case of PV system and the predicted reduction is difficult to determine. This is due to a large number of factors influencing on the emission of gaseous pollutants from livestock buildings and the technical level of the applied reduction method. The environmental effects resulted from investing in a PV system seems to be more predictable, than modernizing livestock buildings.

\section{CONCLUSIONS}

Based on the research and obtained results the following conclusions can be drawn:

- The cost of the photovoltaic system is 157000 PLN (37000 EUR) and the payback time (SPBT) is 12.6 years.

- The use of a photovoltaic system to supply the ventilation system of the piggery reduces $\mathrm{CO}_{2}$ emissions by $19.1 \mathrm{Mg}$ $\mathrm{CO}_{2}$ per year. Covering by PV panels the all southern part of roof would reduce the $\mathrm{CO}_{2}$ emissions by $54.7 \mathrm{Mg} \mathrm{CO}_{2} \cdot \mathrm{yr}^{-1}$.

- The $\mathrm{CO}_{2}$ reduction represents $3 \%$ of the total greenhouse gases emissions from the piggery, expressed in $\mathrm{CO}_{2}$ equivalent. It may increase to $8.6 \%$ in case of installing the maximum number of PV panels system on the southern part of the roof, but it requires the financial support for renewable energy by the government.

\section{REFERENCES}

1. Bey, M., Hamidat, A., Benyoucef, B., Nacer, T. 2016. Viability study of the use of grid connected photovoltaic system in agriculture: Case of Algerian dairy farms, Renewable and Sustainable Energy Reviews, Vol. 63, pp. 333-345. https://doi.org/10.1016/j.rser.2016.05.066 
2. Emission factors and fuel heating values and typical meteorological and climatic data for energy calculations of buildings. 2017. Ministry of Infrastructure and Constriction, Warsaw, Poland. Available at http://mib.gov.pl/2Wskazniki emisji wartosci opalowe paliwa.htm (Accessed on 08/11/2017) [In Polish]

3. Hosenuzzaman M. , Rahim N.A., Selvaraj J., Hasanuzzaman M., Malek A.B.M.A., Nahar A. 2015. Global prospects, progress, policies, and environmental impact of solar photovoltaic power generation. Renew Sustain Energy Reviews, Vol. 41, pp. $284-297$. https://doi.org/10.1016/j.rser.2014.08.046

4. Karkacier, O., Gokalp Goktolga, Z., Cicek A. 2006. A regression analysis of the effect of energy use in agriculture. Energy Policy, Vol. 34, Iss. 18, pp. 3796-3800. https://doi.org/10.1016/j.enpol.2005.09.001

5. KOBIZE, 2017. Emission factors of $\mathrm{CO}_{2}, \mathrm{SO}_{2}, \mathrm{NO}$, $\mathrm{CO}$ i TSP for electric energy based on information from National greenhouse gas and gaseous emissions database for 2015. The National Centre for Emissions Management. Available at http://www.kobize.pl/pl/file/wskazniki-emisyjnosci/id/105/wskazniki-emisyjnosci-dla-energii-elektrycznej-opublikowane-wlutym-2017-r (Accessed on 08/11/2017) [In Polish]

6. Ozkan, B., Akcaoz, H., Fert C. 2004. Energy input-output analysis in Turkish agriculture. Renewable Energy, Vol. 29, Iss. 1, pp. 39-51. https://doi.org/10.1016/S0960-1481(03)00135-6

7. Philipps, S. 2017. Photovoltaics Report. Fraunhofer Institute for Solar Energy Systems, ISE with support of PSE AG, Freiburg, Germany. available at https://www.ise.fraunhofer.de/content/dam/ise/de/documents/publications/studies/PhotovoltaicsReport.pdf (Accessed on 07/11/2017)

8. Program. 2011. Program for Institute of Life Science and Technology for years 2011-2015. "Standardization and monitoring of environmental initiatives, agricultural technology and infrastructural solutions for the security and sustainable development of agriculture and rural areas". WP 1.4 Monitoring of odours and gaseous pollutants emission from agricultural sources, including dust and greenhouse gases.

9. PV market in Poland. 2017. Institute for Renewable Energy. Warsaw, Poland. available at: http://www.cire.pl/pliki/2/2017/raportpv_2017_final_18_05_2017.pdf (Accessed on 07/11/2017) (in Polish)

10. Razykov, T.M., Ferekides, C.S., Morel, D., Stefanakos, E., Ullal, H.S., Upadhyaya, H.M. 2011. Solar photovoltaic electricity: current status and future prospects, Sol Energy, Vol. 85, pp. 1580-1608. https://doi.org/10.1016/j.solener.2010.12.002

11. Romantchik, E., Ríos, E., Sánchez, E., López, I., Sánchez, J.R. 2017. Determination of energy to be supplied by photovoltaic systems for fan-pad systems in cooling process of greenhouses, Applied Thermal Engineering, Vol. 114, pp. 1161-1168. https://doi.org/10.1016/j.applthermaleng.2016.10.011

12. Sampaio, P.G.V., González, M.O.A. 2017. Photovoltaic solar energy: Conceptual framework. Renewable and Sustainable Energy Reviews, Vol. 74, pp. 590-601. https://doi.org/10.1016/j.rser.2017.02.081

13. Sibiński M., Znajdek, K. 2016. Photovoltaic devices and installations. 1st ed., Polish Scientific Publishers PWN, Warsaw, Poland. [In Polish]

14. Soufi, A., Chermitti, A., Triki, N.B. 2013. Sizing and Optimization of a Livestock Shelters Solar Stand-Alone Power System, International Journal of Computer Applications, Vol. 71, No.4, pp. 40-47. https://doi.org/10.1515/pomr-2016-0033

15. Wood, J. 2006. Solar energy in Germany: a market review. Refocus, Vol. 7, Iss. 3, pp. 24-30. https://doi.org/10.1016/S1471$\underline{0846(06) 70569-8}$

16. Xue, J. 2017. Photovoltaic agriculture - New opportunity for photovoltaic applications in China. Renewable and Sustainable Energy Reviews, Vol. 73, pp. 1-9. https://doi.org/10.1016/j.rser.2017.01.098 